\title{
Assessing the predictability of ANB, 1-NB, P-NB and 1-NA measurements on Steiner cephalometric analysis
}

\author{
Ana Cláudia Laureano Navarro, Luiz Sérgio Carreiro², Claudenir Rossato³, \\ Ricardo Takahashi², Carlos Eduardo de Oliveira Lima²
}

Objective: To evaluate, in the initial and final stages of corrective orthodontic treatment, the predictability of the ANB, 1-NB, PNB and 1-NA during case individualization, which considers the characteristics of the patient, professional experience and the mechanics to be used. Methods: Ninety patients were selected at the State University of Londrina (UEL, Brazil), presenting Angle Class I and II malocclusions, treated with and without extraction of four premolars and divided into three groups: Horizontal, balanced and vertical. The cephalometric variables were evaluated in the initial, prognosis and final stages of treatment in order to observe the behavior of the estimates, or how they were higher or lower than the values obtained. Results: It was noticed the influence of the facial pattern on the behavior of the measures examined, the values proposed for the ANB were statistically different from values obtained at the end of the treatment; in the vertical group the final value was the one that most approached the proposed value; regarding 1-NB the values proposed with the Steiner analysis for the balanced and vertical groups were not achieved. For P-NB, there was no difference between genders. For 1-NA it was observed that the values obtained at the end of treatment differ from estimates in the three groups. Conclusions: The limitations of the estimates of the measures do not invalidate its clinical or teaching use, if aware of its deficiencies, the analysis can be used with restrictions.

Keywords: Growth and development. Radiography. Tooth movement.

Objetivo: avaliar, nas fases inicial e final de tratamento ortodôntico corretivo, a previsibilidade das medidas ANB, 1-NB, P-NB, e 1-NA durante a individualização dos casos, onde se consideram as características inerentes do paciente, bem como a experiência do profissional e a mecânica a ser utilizada. Métodos: foram selecionados 90 pacientes, tratados na UEL, apresentando Classes I e II de Angle, tratados com e sem extrações de quatro pré-molares e divididos em três grupos: horizontal, equilibrado e vertical. As grandezas cefalométricas foram avaliadas nas fases inicial, proposta e final de tratamento, com o intuito de observar o comportamento das estimativas, ou seja, o quanto elas foram maiores ou menores que os valores obtidos. Resultados: constatou-se influência do padrão facial no comportamento das medidas analisadas; os valores propostos para o ANB foram estatisticamente diferentes dos valores obtidos ao final do tratamento; no grupo vertical, o valor final foi o que mais se aproximou do valor proposto; em relação à medida 1-NB, os valores propostos durante a elaboração da análise de Steiner para os grupos equilibrado e vertical não foram alcançados. Para medida PNB, não se observou diferença entre os sexos. Na medida 1-NA, foi observado que os valores obtidos ao final do tratamento diferem das estimativas nos três grupos analisados. Conclusão: as limitações das estimativas das medidas não invalidam seu emprego clínico ou didático, desde que, conscientes de suas deficiências, sejam utilizadas com restrições.

Palavras-chave: Crescimento e desenvolvimento. Radiografia. Movimentação dentária.

${ }^{1}$ Specialist in Orthodontics, Londrina State University.

${ }^{2}$ Associate Professor, Londrina State University

${ }^{3}$ Assistant Professor, Londrina State University

» The author reports no commercial, proprietary or financial interest in the products or companies described in this article.
How to cite this article: Navarro ACL, Carreiro LS, Rossato C, Takahashi R, Lima CEO. Assessing the predictability of ANB, 1-NB, P-NB and 1-NA measurements on Steiner cephalometric analysis. Dental Press J Orthod. 2013 MarApr;18(2):125-32.

Submitted: August 18, 2009 - Revised and accepted: October 11, 2011

Contact address: Ana Cláudia Laureano Navarro Rua Jorge Velho, 784 Vila Ipiranga - Londrina-PR, Brazil CEP 86010-600 - E-mail: 1sc@sercomtel.com.br 


\section{INTRODUCTION}

With the development of the cephalostat and the consequent standardization of the radiographs, in 1931, it became possible to carry out several cephalometric analyses based on average angular and linear values, obtained from individuals with normal occlusion and a satisfactory facial profile. ${ }^{4,12}$ These values allow for comparisons with those from the patient, verifying the skeletal and dental pattern and the structures that show discrepancies from the norms, thus making diagnosis and the development of individualized treatment plans possible. ${ }^{27}$

In the mid 40's, Tweed included the movement of the lower incisors in the planning of clinical cases, with the purpose of obtaining an ideal occlusion after an orthodontic treatment. He described that these teeth should present a $90^{\circ}$ angle to the mandibular plane, with a tolerable variation of around $+5^{\circ}$.

In 1948, Downs ${ }^{6}$ determined nine angular and one linear measurement, which described the skeletal and dental patterns of Caucasian North Americans, with an excellent clinical occlusion, thus carrying out the first systematic cephalometric analysis. For the author, despite the considerable variation in type and facial pattern, in order for individuals to present a good functional and esthetic balance, they should possess certain common characteristics of the profile.

Realizing that most orthodontists did not call upon cephalometry as a clinical diagnosis resource, since they saw it as a purely scientific instrument used for research purposes, Steiner, ${ }^{25-28}$ in the following decade, proposed an analysis based, empirically, on the dentoalveolar compensatory mechanism, which helped professionals to determine the nature of the bad occlusion, making the development of treatment plans more objective. Using the analyses of Downs, Margolis, Riedel, Thompson, and Wylie, combined with some of his own cephalometric values, he established his own analysis for young leucoderms of Anglo-Saxon origin from the United States.

When arguing the value of Steiner's analysis, one must bear in mind the references and the choices available at that time. Jaw functional orthopedics was incipient and not very propagated amongst American orthodontists, therefore, it did not emphasize orthopedic problems such as the lower facial height, the relative length of the jaw and mandible, the facial convexity angle or the measurements of the posterior cranial base..$^{25-28}$
Steiner's analysis was well accepted by many researchers who, mindful of the occurrence of variations related to the different ethnic and racial groups, ${ }^{27,28}$ set out to verify if the values proposed by Steiner could be applied to different population groups. Several studies, mainly in relation to the dental patterns proposed by Steiner $(1-\mathrm{NA}=4 \mathrm{~mm}$ and $1-\mathrm{NB}=4 \mathrm{~mm}$ ), have demonstrated different values from the proposed norm. ${ }^{1,9,16,21,23,29}$ Some authors, concerned with better analyzing and planning their cases, established the ideal cephalometric norms and the acceptable compromises of this analysis to different racial and ethnic groups. ${ }^{29}$

To develop a treatment plan, along with anamnesis and clinical analysis, some diagnostic elements are fundamental, as study models, intraoral x-rays, extraoral X-rays (panoramic and cephalometric) and intraoral and extraoral photographs. Each diagnostic element presents different ways of evaluation. For that purpose, we have used Steiner's analysis to estimate the qualitative and quantitative growth, with a view to establish treatment goals, thus becoming an important tool for the elaboration of treatment plans. Despite being an important tool for the clinician, it presents a certain degree of subjectivity, when it comes to estimating each patient's growth.

The result of an orthodontic treatment can sometimes be distorted by the stubbornness of some researchers who insist on the fact that the statistical averages should match the final objective of the treatment. This has determined the elaboration of this study with the purpose of analyzing, in the final phase of corrective orthodontic treatment, the predictability of the measurements ANB, 1-NB, P-NB, and 1-NA, estimated on the individualization of Steiner's analysis, considering horizontal, balanced and vertical growth patterns.

\section{MATERIAL AND METHODS \\ Material \\ Sample collection}

We randomly evaluated 300 patient files obtained from the Londrina State University Orthodontics Specialization Course databank and analyzed two lateral cephalometric radiographs from each file, totaling 600 x-rays from patients with Class I and Class II Angle malocclusions, who had their treatment ended. From the initial total of 300 files we selected 90 , from which 36 were male and 54 female, to compose the final sample. 


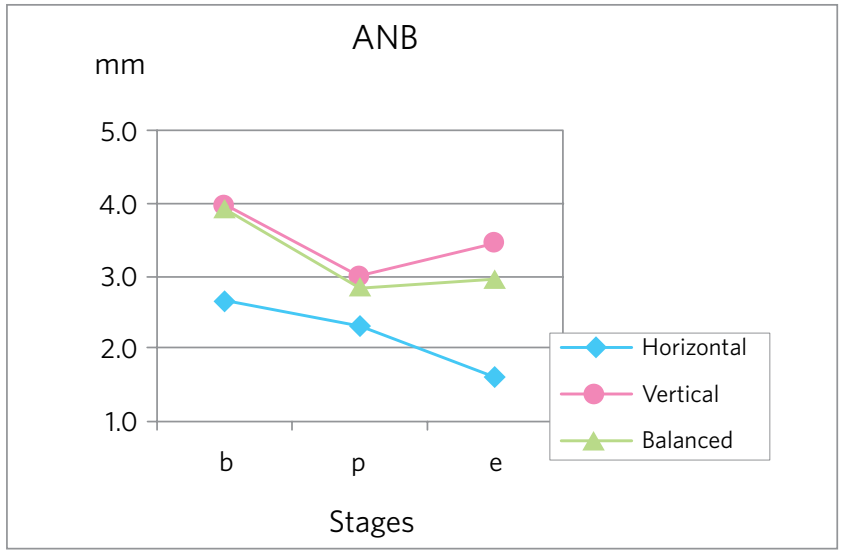

Figure 1 - Average behavior for ANB at the beginning (b) and at the end (e) of treatment, mediated by the proposed value $(\mathrm{p})$.

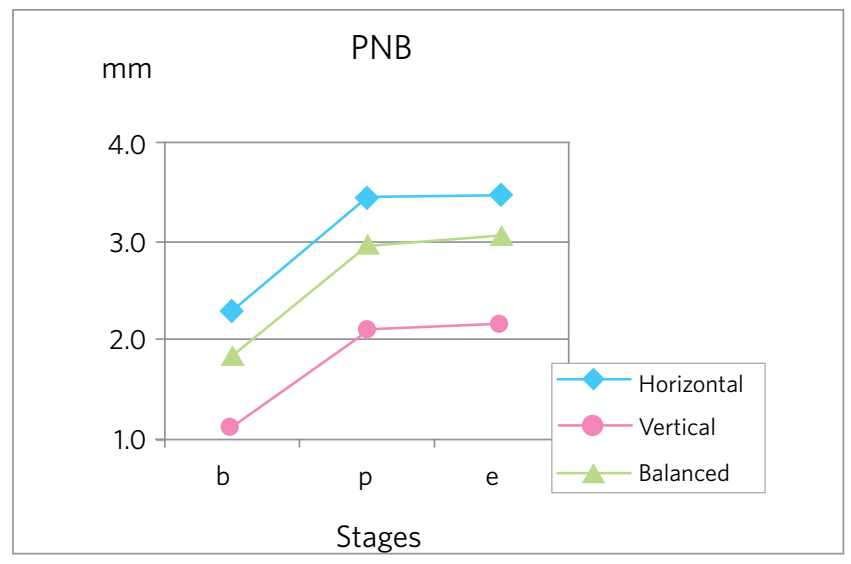

Figure 3 - Average behavior of PNB at the beginning (b), at the end (e) of treatment, mediated by the proposal (p).

ANB, 1-NB, P-NB and 1-NA cephalometric measurements were collected from the patients' files and the individualizations were done by Professors from the Course of Orthodontics, Londrina State University. After the analysis, the research was approved by the Ethics Committee under CEP opinion $n^{\circ}$ 042/08. The following inclusion factors were considered for sample selection.

\section{Inclusion factors}

» Patients with Angle Class I and Class II malocclusion, treated with or without extractions.

" Patients with no deleterious oral habits.

»Cases that were well finished, both esthetically and functionally, with complete initial and final records.

» Patients treated at the Orthodontics Specialization Course of the Londrina State University.

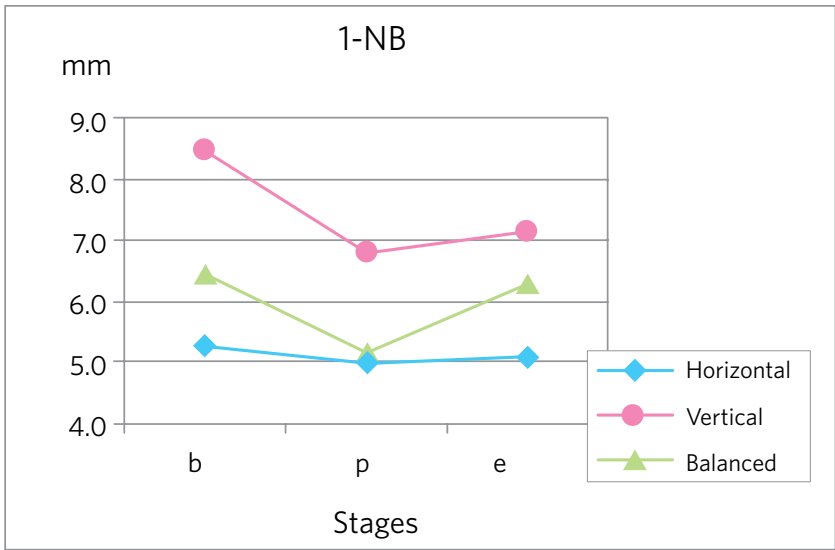

Figure 2 - Average behavior for 1-NB at the beginning (b) the end (e) treatment, mediated by the proposed value ( $p)$.

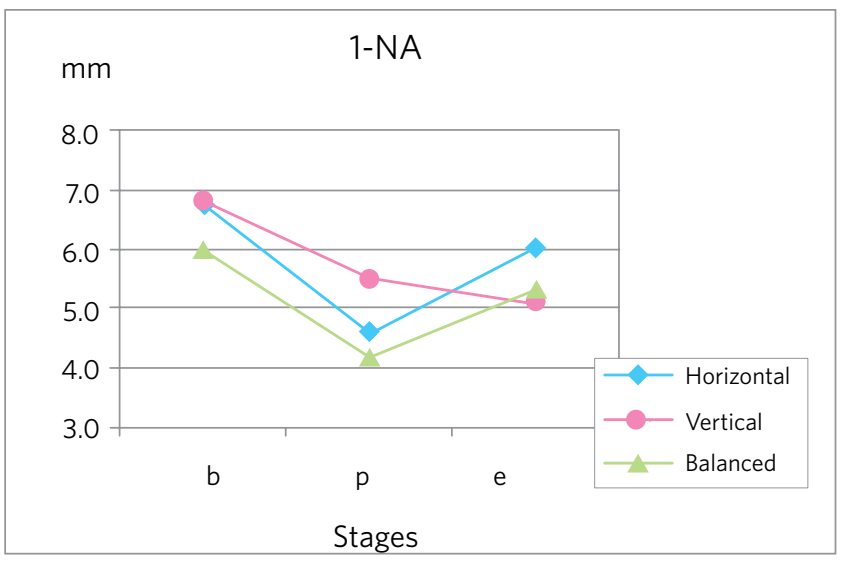

Figure 4 - Average behavior 1-NA at the beginning (b) and at the end (e) of treatment, mediated by the proposal $(p)$.

» Lateral cephalometric radiographs taken with a Polomex-Siemens cephalometric device, model Orthopantomagraph 10E-0P10-EE60-Uel 73180, serial number 62249, Yoshida-Cephlo. expure, manufacturing/inclusion year 1992;

Since one of the criteria to estimate values during the individualization of each case consists of the evaluation of the growth pattern and that this pattern (dolichocephalic, mesocephalic and brachycephalic) exerts a greater influence on growth than the anterior-posterior relation (Class I and Class II), the sample was divided, according to the craniofacial growth in three groups:

»Horizontal group $(\mathrm{H})$ : 11 female and 3 male.

»Balanced group (E): 11 female and 14 male.

»Vertical group (V): 32 female and 19 male. 
The craniofacial growth pattern was established using SN.GoGn cephalometric measurements. Despite the existing controversy in the literature related to the reliability of the Sela-Nasio line, we opted for this measurement, mainly because it was advocated by Stein$\mathrm{er}^{25,26,27,28}$ in his cephalometric analysis proposition.

The Craniofacial Growth Atlas, published by Martins et $\mathrm{a}^{15}$ was used to divide the groups, since it offers the average values and their respective standard deviations from the selected measurement, and it was elaborated on a sample of Brazilians of Mediterranean descent. Since the corrective orthodontic treatment begins at around 12 years of age, the values for SN.GoGn were checked at that age, obtaining the measurements of 33.20 for the female genre and 34.30 for the male genre, and the limits for the balanced group of 28.20 to 38.20 for females and 30.30 to 38.60 for males. The horizontal group was classified from values below the inferior limits, and the vertical, above the superior limits.

Cephalometric growths were evaluated in the initial, proposed and final phases of the treatment. We also verified the differences between the final and the proposed phases to observe the behavior of the estimates, checking how higher or lower they were compared to the obtained values.

\section{RESULTS AND DISCUSSION}

Since Steiner's analysis is used all over the world and is considered an important tool for teaching and for the systemization of diagnosis and the elaboration of treatment plans, we tried, with this research, to establish a critical view of the way in which the analysis is being employed, as well as possible adjustments that the results of the research might suggest.

\section{Predictability of the ANB angle}

By observing the behavior of the initial and final ANB angle, we realized that it became smaller with age, more significantly in the horizontal group, and not in the vertical and balanced groups, whose final value was higher than the proposed value, which corroborates with the findings of Bishara, ${ }^{3}$ Coura et $a 1,{ }^{5}$ Silva et $\mathrm{al}^{24}$ and the Craniofacial Growth Atlas. ${ }^{15}$

The proposed values for the initial and final ANB angles (Fig 1 and Table 1) were statistically different from the values obtained at the end of the treatment, with the exception of the balanced group. In reality, there was a greater variation only in the horizontal group, different from the results found by Ortiz et $\mathrm{al}^{18}$ whose final values were similar to the proposed estimates.

The horizontal group had the proposed value for the ANB angle higher than the final value from all the groups. This probably occurred due to the greater potential for mandibular growth, contributing to the reduction of this angle.

Results obtained by this research for the ANB angle corroborates with the findings of Farret ${ }^{7}$ and Ortiz et al, ${ }^{18}$ who utilized a similar methodology and obtained values that were very close to the proposed at the end of the treatment.

When comparing the three groups studied in relation to gender interference in the resulting values, results from the analysis of variance (ANOVA) showed no differences between them. This shows that the main effect, observed only in the horizontal group, is distributed equally between the male and female genders.

By comparing ANB angle averages at the initial and final phases with the proposed phase, we verify, through the paired $t$ test, that there was a significant statistical difference between the proposed and the final stages of treatment (Table 1).

Rate of accuracy was reduced in the three groups, showing greater tendency to underestimate the reduction of the ANB angle, mainly in the horizontal group, which has greater growth potential (Table 2). Meanwhile, in the differences averages between the final and the proposed phases, the numeric values were clinically low.

From these results, it is possible to find the deficiency in the individualization of the estimates, mainly for the horizontal group, which leads to the need to avoid the underestimation of the mandibular growth potential with this age group and with both sexes. Based on these results, one can state that the ANB estimates have limitations and should not be taken as rigid parameters for the finishing of orthodontic treatment.

\section{Predictability of the 1-NB measurement}

The Holdaway principle, where the distances P-NB and 1-NB must be equal or vary within a $2 \mathrm{~mm}$ limit, was introduced by Steiner ${ }^{26}$ in his analysis in 1959. This proportion was analyzed with young Brazilians, with normal occlusion and its use during diagnosis and treatment plan developments is indicated in literature. ${ }^{7}$ 
Silva and Martins ${ }^{24}$ conducted a study with young Caucasian Brazilians with normal occlusion, demonstrating that the 1-NB measurement for this population is larger than the ideal values advocated by Steiner. ${ }^{25,26,27,28}$

In relation to the 1-NB measurement (Fig 2), results from this study shows that in the balanced and mainly in the horizontal group, a retrusion of the lower incisors is proposed, while in the horizontal group it was estimated that the lower incisors practically did not suffer any changes in relation to their angles of protrusion. At the end of the treatment, we observed retrusion in all groups, however, the proposed values during the elaboration of Steiner's analysis for the balanced and vertical groups were not reached. A similar behavior was observed by Farret, ${ }^{7}$ who also verified a tendency to underestimate the values of the 1-NB measurement (averages obtained for 1-NB proposed $3.62 \mathrm{~mm}$ and final $4.98 \mathrm{~mm}$ ), concluding that the use of Steiner's analysis must be carried out with great caution and criteria for Brazilians with Class I occlusions, since the acceptable compromises underestimate the average position of the incisors.

Ramos et $\mathrm{al}^{22}$ and Hasund ${ }^{11}$ emphasize the importance of taking into consideration the fact that the $1-\mathrm{NB}$ measurement is larger in the cases where the growth pattern is divergent and smaller than a convergent growth pattern, during the elaboration of Steiner's analysis.

In the current evaluation, we verify a significant statistical difference between the proposed values and the ones obtained at the end of the treatment for the vertical and balanced groups (Table 3). We observed that these values were underestimated, just as in the studies of Farret ${ }^{7}$ and Pinzan et $\mathrm{al},{ }^{20}$ since the estimated P-NB for both groups did not present a significant difference in relation to the obtained value, and the value of 1-NB appeared higher for youths with a vertical growth pattern. ${ }^{11,22}$

Table 1 - Test result for the comparison between proposed values ( $p$ ) and the values at the end of treatment (e) for the ANB angle.

\begin{tabular}{|c|c|c|c|c|c|c|}
\hline Facial type & $\begin{array}{l}\text { Initial } \\
\text { average }\end{array}$ & $\begin{array}{l}\text { Proposed } \\
\text { average }\end{array}$ & $\begin{array}{c}\text { Average after } \\
\text { treatment }\end{array}$ & $\begin{array}{c}\text { Difference } \\
e-p\end{array}$ & $p$-value & Test \\
\hline Horizontal & 2.65 & 2.30 & 1.60 & -0.70 & $2.9 \%$ & Student $t$ test \\
\hline Vertical & 3.96 & 3.00 & 3.43 & 0.43 & $23.37 \%$ & Student $t$ test \\
\hline Balanced & 3.93 & 2.82 & 2.96 & 0.14 & $54.68 \%$ & Student $t$ test \\
\hline
\end{tabular}

Table 2 - Number and rate of accuracy (=) of the proposed value, of a larger final value $(>)$, or smaller $(<)$ than the estimates of the ANB measurement (e-p).

\begin{tabular}{cccc} 
Groups & Accuracy & Larger & Smaller \\
& $=$ & $>$ & \multicolumn{1}{c}{ Total } \\
Horizontal & $6(24 \%)$ & $7(28 \%)$ & $12(48 \%)$ \\
Balanced & $9(17 \%)$ & $22(43 \%)$ & $20(39 \%)$ \\
Vertical & $3(22 \%)$ & $7(50 \%)$ & $4(28 \%)$ \\
\hline
\end{tabular}

Table 3 - Comparison between proposed values ( $p)$ and the values at the end of treatment (e) for 1-NB.

\begin{tabular}{|c|c|c|c|c|c|c|}
\hline Facial type & $\begin{array}{l}\text { Initial } \\
\text { average }\end{array}$ & $\begin{array}{l}\text { Proposed } \\
\text { average }\end{array}$ & $\begin{array}{c}\text { Average after } \\
\text { treatment }\end{array}$ & $\begin{array}{c}\text { Difference } \\
e-p\end{array}$ & p-value & Test \\
\hline Horizontal & 5.26 & 4.96 & 5.10 & 0.14 & $68.22 \%$ & Student $t$ test \\
\hline Vertical & 8.46 & 6.79 & 7.11 & 0.32 & $85.55 \%$ & Wilcoxon \\
\hline Balanced & 6.41 & 5.14 & 6.27 & 1.13 & $0.01 \%$ & Wilcoxon \\
\hline
\end{tabular}

Table 4 - Number and rate of accuracy $(=)$ for the proposed value, for a larger final value $(>)$, or smaller $(<)$ than the estimates of the 1-NB measurement (e-p).

\begin{tabular}{cccc} 
Groups & Accuracy & Larger & Smaller \\
& $=$ & $>$ & \multicolumn{1}{c}{ Total } \\
Balanced & $6(24 \%)$ & $9(36 \%)$ & $10(40 \%)$ \\
Balanced & $9(17 \%)$ & $34(66 \%)$ & $8(15 \%)$ \\
Vertical & $3(22 \%)$ & $7(50 \%)$ & $4(28 \%)$ \\
\hline
\end{tabular}


Table 5 - Comparison between the proposed values $(p)$ and the values at the end of treatment (e) for P-NB

\begin{tabular}{|c|c|c|c|c|c|c|}
\hline Facial type & $\begin{array}{c}\text { Initial } \\
\text { average }\end{array}$ & $\begin{array}{l}\text { Proposed } \\
\text { average }\end{array}$ & $\begin{array}{l}\text { Average after } \\
\text { treatment }\end{array}$ & $\begin{array}{c}\text { Difference } \\
\text { e-p }\end{array}$ & p-value & Test \\
\hline Horizontal & 2.3 & 3.44 & 3.48 & 0.04 & $85.33 \%$ & Student $t$ test \\
\hline Vertical & 1.10 & 2.11 & 2.18 & 0.07 & $82.10 \%$ & Student $t$ test \\
\hline Balanced & 1.85 & 2.97 & 3.07 & 0.10 & $56.22 \%$ & Signs of posts \\
\hline
\end{tabular}

Table 6 - Number and accuracy rate (=) of the proposed value, of a larger final value ( $>$ ) or smaller $(<)$ than the estimates of the P-NB measurement e-p).

\begin{tabular}{ccccc} 
Groups & Accuracy & Larger & Smaller & Total \\
Horizontal & $3(12 \%)$ & $10(40 \%)$ & $12(48 \%)$ & 25 \\
Balanced & $8(15 \%)$ & $19(37 \%)$ & $24(47 \%)$ & 51 \\
Vertical & $3(22 \%)$ & $6(42 \%)$ & $5(35 \%)$ & 14 \\
\hline
\end{tabular}

By evaluating the behavior of the 1-NB estimates considering the growth pattern and/or gender, we verified, in the balanced group, the same behavior for both genders. For the horizontal and vertical groups, we verified that, at the end of the orthodontic treatment, horizontal individuals of the female gender presented 1-NB larger than the proposed, horizontal individuals of the male gender presented 1-NB smaller than the proposed, vertical individuals of the female gender presented 1-NB smaller than proposed, and, finally, vertical individuals of the male gender presented 1-NB larger than the proposed. Thus, we have an inverted behavior between men and women, according to their facial type. Gender influence was also found by Pinzan, ${ }^{20}$ but only in the vertical group.

The rate of accuracy was low for all facial types, where the margin of error for high values was higher in the balanced group, lower for the horizontal group and also higher for the vertical group (Table 4).

Since Steiner's acceptable compromise table underestimates the positioning of the lower incisors for young Caucasian Brazilians, we emphasize the need to individualize the values for this population.

\section{Predictability of the P-NB measurement}

The P-NB measurement was considered indispensable by Steiner ${ }^{26}$ in his analysis, however, he did not specified the factors that subsidized his calculations, emphasizing the role represented by the clinical experience, pattern, growth potential and gender of the patient.

Holdaway's 1:1 proportion, with a tolerance limit of $3 \mathrm{~mm}$, was verified in young Brazilians with normal occlusion, and, therefore, its use during the diagnostic and treatment plan elaborations is indicated in literature.,17

By analyzing the P-NB measurement in all its stages, we verified, through Figure 3, that there was no difference between the proposed and the end values in all studied groups, which was also verified by Ramos et al. ${ }^{2}$ However, they emphasize that the occurrence of individual variations in this region might have masked the P-NB's tendency to be smaller in the vertical group.

Bishara et $\mathrm{al}^{2,3}$ described higher values for the P-NB in horizontal patients and lower in vertical ones, which is explained by Bishara, ${ }^{2}$ and influenced by jaw rotation. Pinzan et $\mathrm{a}^{19}$ found differences in their study for the proposed values in relation to the end-of-treatment values in the horizontal and balanced groups, whilst in the vertical group this difference was not noted. By comparing the averages of the P-NB in the initial and final stages with the proposed stage, we verified, through the paired " $t$ " test, that there was no statistically significant difference between the proposed and final stages of treatment, determining a correct growth estimate in the anterior region of the $\operatorname{chin}^{8}$ (Table 5). We observed no 
Table 7 - Number and accuracy rate $(=)$ of the proposed value, of a final larger value $(>)$ or smaller $(<)$ than the estimates of the 1-NA measurement (e-p).

\begin{tabular}{cccc}
\hline Groups & Accuracy & Larger & Smaller \\
& $=$ & $17(68 \%)$ & $7(28 \%)$ \\
Horizontal & $1(4 \%)$ & $10(19 \%)$ & 25 \\
Balanced & $10(19 \%)$ & $51(60 \%)$ & $6(42 \%)$ \\
Vertical & $2(14 \%)$ & $6(42 \%)$ & 14 \\
\hline
\end{tabular}

Table 8 - Test result for the comparison between the proposed values ( $p$ ) and the values at the end of the treatment (e) for 1-NA angle.

\begin{tabular}{|c|c|c|c|c|c|c|}
\hline Facial Type & $\begin{array}{c}\text { Initial } \\
\text { average }\end{array}$ & $\begin{array}{l}\text { Proposed } \\
\text { average }\end{array}$ & $\begin{array}{c}\text { Average after } \\
\text { treatment }\end{array}$ & $\begin{array}{c}\text { Difference } \\
\text { e-p }\end{array}$ & p-value & Test \\
\hline Horizontal & 6.78 & 4.60 & 6.02 & 1.42 & $0.21 \%$ & Student $t$ test \\
\hline Vertical & 6.82 & 5.51 & 5.07 & -0.44 & $57.99 \%$ & Student $t$ test \\
\hline Balanced & 5.97 & 4.19 & 5.31 & 1.12 & $<0.01 \%$ & Signs of posts \\
\hline
\end{tabular}

difference between gender, since both presented measurements statistically similar to those proposed by the analyses of Steiner ${ }^{25,26,27}$ and Pinzan. ${ }^{20}$ The equivalence observed in this study is due, possibly, to the underestimation in the horizontals and the overestimation in the verticals, i.e., they have not suffered the influence of Steiner' ${ }^{25,26,27}$ maxim "the more it has, the more it will have and vice versa" (Table 6)

\section{Predictability of the 1-NA measurement}

The value of the 1-NA measurement was underestimated at the time of the Steiner's individualization analysis on all three groups. As one can see in Table 7, the accuracy rate of the estimates was reduced. Values tend to overestimate the protrusion of the upper incisor in the horizontal and vertical groups, a result that agrees with those obtained by Silva ${ }^{24}$ and the Craniofacial Growth Atlas, ${ }^{15}$ confirming what would be a characteristic and/or preference of Brazilians for more protruding incisors. These results are also found in the limits of the average values found by Harris et al. ${ }^{10}$

The values obtained at the end of the treatment differ from the estimates in the horizontal and balanced groups, differently from the vertical group, where the values are closer to those projected by Steiner. ${ }^{25}$ This result was also found in the work conducted by Farret ${ }^{7}$ in his Class I sample, where values were very similar for all groups (Fig 4). The average values for 1-NA, at the end of the treatment differ from the "ideal" value advocated by Steiner ${ }^{25}$ in all facial types, differing also from the corresponding acceptable compromise for the ANB angle of 40, which would correspond to the 1-NA measurement equal to $2 \mathrm{~mm}$ since, in the present study, this measurement has the approximate value of 5 to $6 \mathrm{~mm}$. In the study carried out by Kowalski, ${ }^{13,14}$ they presented 1-NA equal to the value advocated by Steiner ${ }^{25}$ (Table 8), even though they differed from the proposed ideal value.

The results of the analysis of variance (ANOVA) comparing the three studied groups as to the interference of the gender for the 1-NA measurement did not show a direct effect. In the horizontal group, female individuals present a significant difference between the proposed and the final measurements, which does not happen to males. In the vertical type, there was no difference, and in the balanced there was only a more accentuated behavior for males in relation to the difference between the proposed and the final measurement.

In the balanced patient group, the error margin for less was greater, in relation to the other groups, or, in other words, the predicted retraction of the upper incisors was greater than the obtained and than what was thought necessary in the proposal. This rigid vision of treatment can, determine unnecessary extractions causing straighter profiles, inconsistent with Brazilian esthetic standards. 


\section{CONCLUSION}

Based on the results obtained and discussed, we were able to conclude that:

" There was no influence of gender on the behavior of measurements ANB, 1-NB, P-NB and $1-\mathrm{NA}$.

"The propositions made after Steiner's analysis elaboration differed significantly from the results obtained with the orthodontic treatment, with the exception of the variable P-NB.

" The proposed values for ANB were statistically different from the values obtained at the end of the treatment, with the exception of the balanced group, considering that the proposed value for the horizontal group was underestimated in relation to the other groups.

"In relation to the 1-NB measurement, the proposed values during Steiner's analysis elaboration for the balanced and vertical groups were not reached.

"For the 1-NA measurement, the obtained values at the end of treatment differ from the estimates on all three analyzed groups. In the vertical group the final value was the one that came closer to the proposed one.

"The limitations of the measurement estimates for ANB, 1-NB, P-NB and 1-NA do not invalidate its use as long as they are used with restrictions.
1. Anderson AA, Anderson AC, Hornbuckle AC, Hornbuckle K. Biological derivation or a range of cephalometric norms for children of African American descent (after Steiner). Am J Orthod Dentofacial Orthop. 2000;118(1):90-100

2. Bishara SE. Facial and dental changes in adolescents and their clinical implications. Angle Orthod. 2000;70(6):471-83

3. Bishara SE, Fahl JA, Peterson LC. Longitudinal changes in the ANB angle and Wits appraisal: clinical implications. Am J Orthod. 1983;84(2):133-9.

4. Broadbent $\mathrm{BH}$. A new X-ray technique and its application to orthodontia. Angle Orthod. 1931;1(2):45-66

5. Coura LC, Pinzan A, Freitas RM. Estudos cefalométrico longitudinal do complexo mandibular em pacientes adultos do sexo masculino tratados ortodonticamente com extração de quatro pré-molares. Ortodontia. 1997;30(1):19-30.

6. Downs WB. Variations in facial relationships: their significance in treatment and prognosis. Am J Orthod. 1948;34(10):812-40

7. Farret MMB, Araújo MCM. Comportamento da análise de Steiner em casos tratados ortodonticamente. Ortodontia. 1981;14(3):164-72

8. Fêo PS. Aumento da distância Pog-NB na adolescência. Estomatol Cult. 1970:4(1):5-14

9. Gleis R, Brezniak N, Lieberman M. Israeli cephalometric standards compared to Downs and Steiner analyses. Angle Orthod. 1990; $60(1): 35-40$

10. Harris JE, Kowalski CJ, Walker GF. Discrimination between normal and class II individual using Steiner's analysis. Angle Orthod. 1972;42(3):212-20.

11. Hasund A, Ulstein $G$. The position of the incisors in relation to the lines NA and NB in different facial types. Am J Orthod. 1970;57(1):1-14.

12. Hofrath $\mathrm{H}$. Problems of standard and methods. In: Krogman WM, Sassoun V. A syllabus in roentgenographic cephalometry. $2^{\text {nd }}$ ed. Philadelphia College Offsets; 1957. cap. 1, p. 9-25

13. Kowalski CJ, Walker GF. The use of incisal angles in the Steiner cephalometric analysis. Angle Orthod. 1972;42(2):87-95.

14. Kowalski CJ, Nasjleti CE, Walker GF. Differential diagnosis of adult male black and white populations. Angle Orthod. 1974;44(4):346-50.

15. Martins DR. Atlas de crescimento craniofacial. São Paulo: Ed. Santos; 1998

16. Miura F, Inove N, Suzuki K. Cephalometric standards for Japanese according to the Steiner analysis. Am J Orthod. 1965;51:288-95.
17. Oliveira JN, Martins DR. Estudo longitudinal e comparativo da variação do pogônio com os incisivos inferiores, em relação à linha NB, em adolescentes brasileiros, leucodermas, de 12 aos 18 anos de idade, com "oclusão normal". Ortodontia. 1978;11(2):99-107.

18. Ortiz MF, Pinzan A, Pinzan C, Martins DR. Previsibilidade das medidas ANB e 1-Na da análise cefalométrica de Steiner. Rev Dental Press Ortod Ortop Facial. 2005:10(1):79-87.

19. Pinzan A. Estudo comparativo da medida P-NB, em adolescentes leucodermas, brasileiras, de origem mediterrânea,com normal e más oclusões (Classe I e Classe II, divisão 1), tratadas ortodonticamente. Ortodontia. 1987:20(1-2):47-51

20. Pinzan CRM, Pinzan A, Freitas MR, Henriques JFC, Almeida MR Estudo da previsibilidade das medidas P-NB e 1-NB na elaboração da análise cefalométrica de Steiner. Rev Dental Press Ortod Ortop Facial. 2004:9(2):23-34

21. Platou C, Zachrisson B. Incisor position in Scandinavian children with ideal occlusion: a comparison with the Ricketts and Steiner standards Am J Orthod. 1983:83(4):341-51.

22. Ramos AL, Almeida RR, Pinzan A, Freitas MR. Influência da divergência facial no posicionamento dentário e das bases apicais, em jovens brasileiros com oclusão normal. Ortodontia. 1996;29(3):44-54.

23. Servoss JM. The acceptability of Steiner's acceptable compromises. Am J Orthod. 1960;46(11):834-47.

24. Silva LG, Martins DR. Determinação dos valores cefalométricos 1.NA 1.NB, 1-NA, 1-NB para adolescentes brasileiros, leucodermas, com "oclusão normal" (estudo longitudinal e comparativo). Ortodontia. 1978;11:108-16

25. Steiner CC. Cephalometrics for you and me. Am J Orthod. 1953:39(10):729-55.

26. Steiner CC. Cephalometrics clinical practice. Angle Orthod. 1959;29(1):8-29.

27. Steiner CC. The use os cephalometrics as an aid to planning and assessing orthodontic treatment. Am J Orthod. 1960;46(10):721-35.

28. Steiner CC. Cephalometrics as a clinical tool. In: Kraus BS, Riedel RA. Vistas in Orthodontics. Philadelphia: Lea \& Fegiber; 1962. p. 131-61

29. Uesato G, Kinoshita Z, Kawamoto T, Koyama I, Nakanishi Y. Steiner cephalometric norms for Japanese and Japanese-Americans. Am J Orthod. 1978;73(3):321-7. 